\title{
Hyperbaric Oxygen Therapy To Reduce Blood Glucose Level On Patients Diabetes Mellitus
}

\author{
Ana Zakiyah, Veni Septian Anggraini \\ STIKes Bina Sehat PPNI Mojokerto \\ Email: zakiyahana80@gmail.com
}

\begin{abstract}
Oxygen hyperbaric therapy is a clinical treatment by inhalation of pure oxygen (FiO2 $=100 \%$ ), resulting in increasing oxygen levels in the blood and tissues. Currently, hyperbaric oxygen therapy is used for additional management in diabetes mellitus. The purpose of this study was to know the effect of hyperbaric oxygen therapy in case of diabetes mellitus to changes in blood glucose level. Type of research was pre-experimental one group pre-test post design. The population in this study was diabetes mellitus patients, so that the sample obtained 47 respondents. Patients were given $100 \%$ oxygen inhalation with a pressure of 2.4 ATA in chamber hyperbaric oxygen. Blood glucose levels were measured before and after hyperbaric oxygen therapy. Glucose levels before the average therapy were $229 \mathrm{mg} / \mathrm{dl}$ and after treatment averaged $159 \mathrm{mg} / \mathrm{dL}$. Statistical analysis with t test showed $\mathrm{p}$ value $0.000<\alpha(0.05)$, so there was the influence of hyperbaric oxygen therapy with decreasing blood glucose level. There are improvements pancreatic beta cell function and increased tissue sensitivity to insulin due to increased oxidative phosphorylation process in pancreatic beta-cell mitochondria to increase ATP production in pancreatic beta cells. Checks need to be done periodically in one period with using the time series method, so that long-term effects can be known and need to be reviewed by the last use of anti-diabetes drugs and insulin
\end{abstract}

Keywords: Blood glucose level, hyhperbaric oxygen. 


\section{Introduction}

Diabetes mellitus and its complications are still a serious public health problem and an important cause of morbidity, mortality and disability rates worldwide. Diabetes Mellitus occurs chronic metabolic disorders with various causes characterized by high blood sugar levels accompanied by carbohydrate, lipid, and protein metabolism disorders as a result of insulin function insufficiency. Insulin insufficiency can be caused by a disorder or deficiency of insulin production by Langerhans beta cells of the pancreas gland or caused by the lack of responsiveness of body cells to insulin (Poretsky, 2010; Ndisang, 2017).

The latest estimate of the International Diabetes Federation (IDF), 382 million people are living with diabetes in the world by 2013 . By 2035 the number is expected to increase to 592 million people, of the 382 million, 175 million of which has not been diagnosed to progress progressively into uncomplicated complications (Infodatin, 2014). Based on Endocrinology Society Data PERKENI (2015) stated that the number of patients in Indonesia has reached 9.1 million people. Indonesia shifted from 7th rank up to the top 5 in the world.

There are five components of management in patients with diabetes mellitus, namely diet therapy, exercise, monitoring, pharmacological therapy, and education (Emawati, 2013). The main goal of diabetes mellitus therapy is to normalize the activity of insulin and blood glucose levels to reduce the occurrence of vascular and neuropathic complications without the occurrence of hypoglycemia and serious disorders in the pattern of patient activity (Smeltzer \& Bare, 2002). Olokoba et al. (2012) also stated that treatment modality including lifestyle modification, obesity treatment, oral hypoglycemic agents, and insulin sensitivity such as metformin, biguanide that reduce insulin resistance, is still the first-line management recommended especially for patients with diabetes mellitus with obesity.

Along with the advancement of technology in the field of health, produce new methods in the effort to cure diseases including diabetes mellitus. One such technology development is hyperbaric oxygen therapy. At first highpressure oxygen therapy is widely used in the handling of various cases of diseases due to diving, but more and more research is trying to reveal the use of high-pressure oxygen is for the handling of various clinical cases. Hyperbaric treatments may be used as primary care or supplementary care (Mahdi et al., 2013).

Hyperbaric Oxygen Treatment (HBOT) is not a new thing. This method has been discovered by Behnke since 1930 to overcome decompression (Decompression syndrome), a disease experienced by divers or underground miners due to sudden drops in pressure, such as decompression illness and gas embolism (Maxfield, William, 2017).

Several studies have shown that the use of high-pressure oxygen in various cases of disease is widespread. Hyperbaric oxygen therapy can also be used in cases of diabetes which can ultimately improve a person's quality of life. This decrease in blood glucose has been a consistent finding in almost all observational studies. The oxygen concentration used in hyperbaric oxygen therapy differs from the oxygen used in the usual oxygen cylinders. $100 \%$ oxygen is given by using a mask, while the air around the body is compressed air at the same pressure. Giving oxygen through hyperbaric therapy accompanied by high pressure will help the rapid distribution of oxygen and is well met in the organs of the body (Paul \& Virginia, 2016).

Hyperbaric oxygen therapy is generally a safe procedure and complications rarely occur while undergoing this therapy, but even so this therapy still has some risks. High oxygen pressure in the room can cause uncomfortable conditions such as pain or a throbbing sensation in the ear. Oxygen hyperbaric therapy if done with the right procedures by trained medical personnel is considered quite safe. To prevent oxygen poisoning, some patients need to take a short break between therapy and "normal" breathing to prevent too much tissue from absorbing oxygen.

The oxygen dose given at the time of therapy must also be ascertained specifically for each person. Medical staff who handle it need to consider medical history, health 
complaints, and the age of the patient to prevent side effects and complications. Some of the symptoms or side effects that may arise after doing hyperbaric oxygen therapy include fatigue and feeling of flying. While more serious complications can occur including lung damage, leakage or discharge from the inner ear, damage to the sinuses, changes in vision, causing nearsightedness or myopia, oxygen poisoning. This can lead to respiratory failure, fluid in the lungs, or seizures (Marvin, He., Sharma, D., Santiago, W \& McCulloch, N, 2017). These side effects are generally mild during hyperbaric oxygen therapy if it lasts more than 2 hours and the pressure in the room is less than 3 times the normal atmospheric pressure.

Based on data obtained at Lakesla Surabaya, the number of patients with diabetes mellitus who do hyperbaric oxygen therapy increasingly longer. The use of high-pressure oxygen dose of 2.4 ATA $3 \times 30$ minutes for $2 \times 5$ days interspersed with one week break can lead to an increase in blood insulin levels in people with diabetes mellitus. This condition is due to the increase of pancreatic beta cells function. Increasing pancreatic beta cells causes the level of insulin in the blood increases. The use of high-pressure oxygen also stimulates the emphasis on the secretion of various hormone counter insulin in the blood such as glucagon. The decrease in blood glucagon levels causes a decrease in blood glucose levels because the main function of glucagon is to increase blood glucose levels. In addition, the provision of high-pressure oxygen can increase metabolism so that glucose consumption also increases and decreases blood glucose levels (Jain, 2016).

The results of interviews with medical officers in Lakesla Surabaya, most patients who do hyperbaric oxygen therapy only measured blood glucose levels before therapy, but no measurement after doing hyperbaric oxygen therapy blood glucose levels. So it can not be known how much influence of hyperbaric oxygen therapy to changes in blood glucose levels. After patients undergo hyperbaric oxygen therapy most feel tired and lethargic or hungry. But after resting for a while, this lethargic feeling will disappear by itself and, patient feels more fit and can continue his activitie. From this problem, researchers want to know the influence of hyperbaric oxygen therapy to changes in blood glucose levels.

\section{Method}

The design of study was pre-experimental (one group pretest-posttest design) which one group measured the intervention before and after treatment (Sugiyono, 2010). The sampling technique used in this research was nonprobability sampling: consecutive sampling. The consecutive sampling technique involves everyone from a population for a certain time interval or a particular sample size (Polit \& Beck, 2010). The sample in this study amounted to 47 respondents who have diabetes mellitus disease type II (NIDDM). Respondents were given hyperbaric oxygen therapy by giving $100 \%$ oxygen inhalation at 2.4 ATA pressure in a special room called hyperbaric chamber oxygen for ten therapies in 1 session ( 1 session consisting of $3 \times 30$ minutes). Before and after hyperbaric oxygen therapy, the respondents measured blood sugar levels. The data was analysed using paired t-test with significance level $\alpha<0.05$.

\section{Result}

Table 1 Characteristics of Respondents $(n=47)$

\begin{tabular}{|c|c|c|c|c|c|}
\hline No & Variable & Category & Frequency & Percentage (\%) & Total (\%) \\
\hline \multirow{2}{*}{1} & \multirow{2}{*}{ Gender } & Male & 23 & 36 & \multirow{2}{*}{100} \\
\cline { 3 - 5 } & & Female & 24 & 64 & \\
\hline \multirow{2}{*}{2} & \multirow{4}{*}{ Age } & $30-39$ years & 5 & 11 & 100 \\
\cline { 3 - 5 } & & $40-49$ years & 7 & 15 & \\
\cline { 3 - 5 } & & $50-59$ years & 20 & 42 & \\
\cline { 3 - 5 } & & $51-59$ years & 13 & 4 & \\
\cline { 3 - 5 } & & $60-69$ years & 2 & & \\
& & & & \\
\end{tabular}


Ana Zakiyah: Hyperbaric Oxygen Therapy To Reduose Level On Patients Diabetes Mellitus

\begin{tabular}{|c|c|c|c|c|c|}
\hline \multirow[t]{4}{*}{3} & \multirow{4}{*}{$\begin{array}{c}\text { Duration } \\
\text { of suffering } \\
\text { Diabetes } \\
\text { Mellitus }\end{array}$} & Under one year & 7 & 15 & \multirow[t]{4}{*}{100} \\
\hline & & $1-10$ years & 25 & 53 & \\
\hline & & 11-20 years & 10 & 21 & \\
\hline & & Over 20 years & 5 & 11 & \\
\hline
\end{tabular}

Most respondents who received hyperbaric oxygen therapy were female $(64 \%)$. There is no hypothesis that sex is related to the incidence of diabetes mellitus, but the prevalence of men more than woman. This is because the diet is difficult to set ( Tjokroprawiro, 2007).

Respondents who underwent hyperbaric oxygen therapy in general aged 50-59 years were $20(42 \%)$. Age affects the risk and the incidence of type 2 diabetes. Age is closely related to the increase in blood sugar levels, so the more aging the prevalence of type 2 diabetes and impaired glucose tolerance is higher. An aging process takes place after age 30 results in anatomical, physiological and biochemical changes.

The age of 30 years, blood glucose levels will rise $1-2 \mathrm{mmol} / \mathrm{dL}$ every year during fasting and will rise $5.6-13 \mathrm{mmol} / \mathrm{dL}$ at 2 hours after meals (Sudoyo, 2009). DM type 2 is the type of DM is the most number that is about $90-95 \%$ of all people with DM and many experienced by adults over 40 years. This is because insulin retention in type 2 DM tends to increase in the elderly (46-65 years), in addition to the history of obesity and the presence of hereditary factors (Karian, M.,Wolfe, BM.,\& Ikramuddin, S, 2016).

The findings mentioned that the respondents who suffer from diabetes mellitus who undergo hyperbaric oxygen therapy were $53 \%(n=25)$. The results of Kalda, Ratsep, \& Lamber (2008), the duration of DM was significantly related to the quality of life of DM type 2 patients low quality of life is present the long duration of DM.

All respondents are diabetes mellitus type NIDDM. This typically occurs due to decreased sensitivity to insulin (so-called insulin resistance), so there is a disruption of sugar delivery to the cell body.

The results showed that the average blood glucose level before hyperbaric oxygen therapy was $229 \mathrm{mmol} / \mathrm{dL}$ and the mean blood glucose level after hyperbaric oxygen therapy was $159 \mathrm{mmol} / \mathrm{dL}$, the mean decrease of blood glucose was $70 \mathrm{mg} / \mathrm{dL}$. Paired T-Test test results obtained data value $\rho=0.000, \alpha=0.05$ then $\rho<\alpha$ means H0 rejected. Giving hyperbaric oxygen therapy is effective in lowering blood glucose levels of patients with diabetes mellitus.

Table 2 Blood Glucose Levels Before and After Hyperbaric Oxygen Therapy

\begin{tabular}{|c|c|c|c|c|}
\hline \multirow{2}{*}{ Code } & \multirow{2}{*}{ Pressure } & \multicolumn{3}{|c|}{ Glucose levels (mmol/dL) } \\
\cline { 3 - 5 } & & $\begin{array}{c}\text { Before session } \\
(\mathrm{mmol} / \mathrm{dL})\end{array}$ & $\begin{array}{c}\text { End of session } \\
(\mathrm{mmol} / \mathrm{dL})\end{array}$ & $\mathbf{2 1 8}$ \\
\hline 1 & 2,4 ATA & 276 & 126 & 170 \\
\hline 2 & 2,4 ATA & 296 & 108 & 65 \\
\hline 3 & 2,4 ATA & 173 & 174 & 44 \\
\hline 4 & 2,4 ATA & 218 & 197 & 56 \\
\hline 5 & 2,4 ATA & 253 & 149 & 99 \\
\hline 6 & 2,4 ATA & 248 & 128 & 15 \\
\hline 7 & 2,4 ATA & 143 & 334 & 72 \\
\hline 8 & 2,4 ATA & 406 & 135 & 46 \\
\hline 9 & 2,4 ATA & 218 & 108 & 32 \\
\hline 10 & 2,4 ATA & 154 & 172 & 67 \\
\hline 11 & 2,4 ATA & 204 & 206 & 44 \\
\hline 12 & 2,4 ATA & 273 & 276 & 83 \\
\hline
\end{tabular}


Ana Zakiyah: Hyperbaric Oxygen Therapy To Reduose Level On Patients Diabetes Mellitus

\begin{tabular}{|c|c|c|c|c|}
\hline 14 & 2,4 ATA & 232 & 134 & 98 \\
\hline 15 & 2,4 ATA & 159 & 139 & 20 \\
\hline 16 & 2,4 ATA & 225 & 178 & 47 \\
\hline 17 & 2,4 ATA & 182 & 161 & 21 \\
\hline 18 & 2,4 ATA & 158 & 109 & 49 \\
\hline 19 & 2,4 ATA & 250 & 198 & 52 \\
\hline 20 & 2,4 ATA & 291 & 126 & 165 \\
\hline 21 & 2,4 ATA & 173 & 104 & 69 \\
\hline 22 & 2,4 ATA & 234 & 174 & 60 \\
\hline 23 & 2,4 ATA & 253 & 180 & 73 \\
\hline 24 & 2,4 ATA & 256 & 145 & 111 \\
\hline 25 & 2,4 ATA & 143 & 123 & 20 \\
\hline 26 & 2,4 ATA & 385 & 256 & 129 \\
\hline 27 & 2,4 ATA & 218 & 135 & 83 \\
\hline 28 & 2,4 ATA & 154 & 105 & 49 \\
\hline 29 & 2,4 ATA & 204 & 146 & 58 \\
\hline 30 & 2,4 ATA & 283 & 206 & 77 \\
\hline 31 & 2,4 ATA & 320 & 234 & 86 \\
\hline 32 & 2,4 ATA & 232 & 110 & 122 \\
\hline 33 & 2,4 ATA & 159 & 100 & 59 \\
\hline 34 & 2,4 ATA & 235 & 178 & 57 \\
\hline 35 & 2,4 ATA & 182 & 111 & 71 \\
\hline 36 & 2,4 ATA & 158 & 109 & 49 \\
\hline 37 & 2,4 ATA & 298 & 218 & 80 \\
\hline 38 & 2,4 ATA & 301 & 126 & 175 \\
\hline 39 & 2,4 ATA & 173 & 112 & 61 \\
\hline 40 & 2,4 ATA & 218 & 167 & 51 \\
\hline 41 & 2,4 ATA & 253 & 176 & 77 \\
\hline 42 & 2,4 ATA & 258 & 149 & 109 \\
\hline 43 & 2,4 ATA & 143 & 112 & 31 \\
\hline 44 & 2,4 ATA & 257 & 200 & 57 \\
\hline 45 & 2,4 ATA & 218 & 135 & 83 \\
\hline 46 & 2,4 ATA & 167 & 108 & 59 \\
\hline 47 & 2,4 ATA & 199 & 172 & 27 \\
\hline
\end{tabular}

\section{Discussion}

In this study found changes in blood glucose levels after hyperbaric therapy. The results of statistical analysis also showed that hyperbaric oxygen therapy can reduce glucose levels in the blood in people with diabetes mellitus ( $\rho$ value $=0.000, \alpha=0.05$ )

The therapeutic mechanism of hyperbaric oxygen therapy (HBO2) action is based on an increase in partial O2-inspired pressure and hydrostatic pressure. Increased hydrostatic pressure increases the partial pressure of the gas and causes a reduction in the volume of gas-filled space under Boyle's law. The reduction in gas volume has direct relevance to treating pathological conditions in which bubbles of gas are present in the body, such as arterial embolism and decompression diseases (Camporesi \& Bosco, 2014; Jain, 2016).

At the time of hyperbaric oxygen therapy, 
hemoglobin in the venous veins is also fully saturated so that the oxygen pressure increases in the blood vessels. Diffusion oxygen depends on the pressure difference so that oxygen will be channeled to the tissue from the blood vessels. The oxygen in blood soluble in the plasma fluid binds to hemoglobin, and only a small part is found in the soluble form. Oxygen-soluble form in hyperbaric oxygen therapy is more easily consumed by the tissues through direct diffusion than oxygen-bound oxygen through the hemoglobin system (Guritno, 2005; Collins, 2015).

Karadurmus (2010), explains that hyperbaric oxygen therapy provides beneficial effects in diabetic patients with recovery of vascular reactivity through modulation of vasoconstrictor and vasodilator production as well as increased vascular sensitivity to these factors. Hyperbaric oxygen therapy can alter the expression of cyclooxygenase 2 (COX2 ), endothelial nitric oxide synthase (eNOS) in experimental and local nitric oxide (NO) systems, thereby showing an improvement in diabetic foot patients responsive to $\mathrm{HBO}$ treatment. All risk factors for atherosclerosis in diabetics are strongly linked to each other, potential effects of $\mathrm{HBO}$ on endothelial function. Endothelial dysfunction is closely related to the development of diabetic retinopathy, nephropathy, and atherosclerosis in diabetes. In addition, endothelial dysfunction is closely related to insulin resistance, so tissue sensitivity to insulin improves vascular endothelial function and vice versa.

In theory, HBO therapy can increase tissue sensitivity to insulin and lead to a decrease in blood sugar levels The use of high-pressure oxygen doses of 2.4 ATA $3 \times 30$ minutes for $2 \times 5$ days interspersed with one week break can lead to an increase in blood insulin levels in people with diabetes mellitus. This condition is due to the increased function of pancreatic beta cells, the increase of pancreatic beta cells causes blood insulin levels to increase (Ishihara, 2007; Jain, 2016).

This is supported by several studies including the Wilkinson (2012) study, patients with diabetes mellitus given $100 \%$ oxygen inhalation at absolute 2.0 atmospheric pressure for 2 hours, six sessions per week for five weeks. Hyperbaric oxygen therapy can reduce fasting blood glucose in individuals with type 2 diabetes. This is due to an increase in peripheral insulin sensitivity by a hyperinsulinaemic euglycaemic clamp. Insulin sensitivity increased within three days of hyperbaric oxygen treatment, and this was maintained for 30 sessions.

Peleg et al. (2013), states that blood glucose can decrease significantly after hyperbaric oxygen therapy. Insulin-dependent patients had no change in blood glucose levels either during HBOT $(13.0 \pm 4.0 \mathrm{mmol} \mathrm{L}-1$ before $13.2 \pm 5.7 \mathrm{mmol} \mathrm{L}-1$ after, $\mathrm{P}=0.88$ ) or during control sessions ( $13.15 \pm 2.7$ before it became $13.2 \pm 4.7 \mathrm{mmol} \mathrm{L-1}$ after that, $\mathrm{P}=0.96)$. NIDDM patients experienced significant decreases in blood glucose during both sessions; from $9.2 \pm 3.0 \mathrm{mmol} \mathrm{L}-1$ to 7.3 $\pm 3.0 \mathrm{mmol} \mathrm{L}-1 \quad(\mathrm{P}=0.047)$ during HBOT and from $9.9 \pm 2.9$ to $7.8 \pm 3.4 \mathrm{mmol} \mathrm{L}-1(\mathrm{P}$ $=0.004$ ) during the control session.

The increase function of pancreatic beta cells is possible because this high-pressure oxygen causes an increase in the oxidative phosphorylation process (OXPHOS) in the pancreatic beta-cell mitochondria. The increase in the OXPHOS process is due to increasing enzyme dehydrogenase activity such as the enzyme glyceraldehyde phosphate dehydrogenase (GPDG), an enzyme that acts on the oxidation of NADH and enzyme succinic dehydrogenase (SDG), an enzyme that acts on the oxidation of FADH2 to FAD. The increase of OXPHOS process will increase the production of ATP in pancreatic beta cells increased.

Increasing secretion of insulin in the blood will cause a decrease of glucose levels in blood. The use of high-pressure oxygen also stimulates the emphasis on the secretion of various hormone counter insulin in the blood such as glucagon. Decreasing glucagon levels in the blood cause a decrease in blood glucose levels.

\section{Conclusions}

Improvement or enhancement of pancreatic beta cell function and tissue sensitivity to insulin are the result of increasing oxidative phosphorylation process in pancreatic beta- 
cell mitochondria. It can increase the ATP production so that hyperbaric oxygen therapy can increase insulin resistance to tissue.

This study was not evaluate the last time the use of drugs either insulin or antidiabetic oral drugs and type of diabetes mellitus, there is a need of further study that would control other factors that would affect blood glucose levels during hyperbaric oxygen therapy.

\section{References}

Camporesi,E.M, \& Bosco, G. (2014). Mechanisms of action of hyperbaric oxygen therapy. Undersea Hyperbaric Medical Society. May-Jun, 41 (3): 247-52. Retrieved from https://www.ncbi.nlm.nih.gov/ pubmed/24984320.

Collins,J.A., Rudenski, A., Gibson, J., Howard, L., \& O'Driscoll, R. (2015). Relating oxygen partial pressure, saturation and content: the hemoglobin-oxygen dissociation curve. Breathe. 11: 194-201. doi: 10.1183/20734735.001415.

Emawati. (2013). Penatalaksanaan keperawatan diabetes mellitus terpadu. Jakarta: Penerbit Mitra Wacana Medika.

Guritno, M. (2005). A hyperbaric oxygen therapy in treatment of diabetic foot. the indonesian orthopaedic. Association. 50th continuing orthopaedic association. Mataram. 4-5.

Marvin, Heyboer., Sharma, Deepali., Santiago, illiam \& McCulloch, Norman. (2017). Hyperbaric Oxygen Therapy: Side Effects Defined and Quantified. Advances In Wound Care, Volume 6, Number 6. https:// dx.doi.org/10.1089\%2Fwound.2016.0718.

Infodatin. (2014). Situasi dan Analisis Diabetes. Kementrian Kesehatan RI. file://C:/Users/User/Downloads/Documents/ infodatin-diabetes.pdf.

Ishihara, A. (2007). Hyperbaric expossure in rate mascle and nerve laboratory of metabolism graduate school of human genomic drug discovery science. Japan:
Kyoto university.

Jain, Kewal, K. (2016). Textbook of Hyperbaric Medicine. Switzerland. Retrieved from https://books.google.co.id/books?id= WV6XDQAAQBAJ\&printsec $=$ frontcover\& $\mathrm{dq}=$ Jain,+ Kewal+K. $+(+2016+) .+$ Textbook + of + Hyperbaric + Medicine. + Sixth + edition\&h $1=$ en $\&$ sa $=$ X\&ved $=0$ ahUKEwjqjeu9qNnaAh VDnJQKHYoFDbgQ6AEIKTAA\#v=onepag e\&q\&f=false.

Kalda, R., Ratsep, A.,\& Lamber,M. (2008). "Predictors of quality of life of patient with type 2 diabetes". Patient Prefer Adherence. 2. $21-26$.

Karadurmus, N., Sahin, M., Tasci,C., Naharci, I., Ozturk, C., Ilbasmis, S., \& Zeki Dulkadir, Z. (2010). Potential benefits of hyperbaric oxygen therapy on atherosclerosis and glycaemic control in patients with diabetic foot. Journal of endocrinology, 61 (3), 275279.

Karian, Marina.,Wolfe, Bruce M.,\& Ikramuddin, Sayeed. (2016). Metabolic Syndrome and Diebetes. New York: Springer Science \& Bussines Media. Retrieved from https://books.google.co.id/books?id=ptM LCwAAQBAJ\&printsec $=$ frontcover $\& \mathrm{dq}$ $=$ diabetes + mellitus,+ medical + surgery $\&$ hl $=\mathrm{id} \& \mathrm{sa}=\mathrm{X} \& \mathrm{ved}=0$ ahUKEwiAvtXXsafgA $\mathrm{hXLqY}$ 8KHcMLDvcQ6AEILDAA\#v $=\mathrm{o}$ nepage \&q=diabetes $\% 20$ mellitus $\% 2 \mathrm{C} \% 20$ medical $\% 20$ surgery \&f=false.

Mahdi. H et al. (2013). Ilmu kesehatan penyelaman dan hiperbarik. Surabaya. Lakesla.

Maxfield, William. (2017). The Oxygen Cure. A Complete Guide to Oxygen Hyperbaric Therapy. Humanic Book Publishing. Retrieved from https://books.google.co.id/ books? $\mathrm{id}=4 \mathrm{RqODQ} A A Q B A J \&$ printsec $=\mathrm{f}$ rontcover \& dq=hyperbaric + oxygen + therap $\mathrm{y} \& \mathrm{hl}=\mathrm{id} \& \mathrm{sa}=\mathrm{X} \& \mathrm{ved}=0 \mathrm{ahUKEwiGxeO98}$ 6TgAhVCv48KHfQhB0YQ6AEIQTAD\# $\mathrm{v}=$ onepage \& $\mathrm{q}=$ hyperbaric $\% 20$ oxygen $\% 20$ therapy $\& \mathrm{f}=$ false.

Ndisang, J.F.,Vannacci, A., \& Rastogi, 
Ana Zakiyah: Hyperbaric Oxygen Therapy To Reduose Level On Patients Diabetes Mellitus

A.(2017). Insulin resistensi, type 1 dan type 2 diabeties, and related complications. Journal of Diabetes Research. Article ID 1478294. Retrieved from https://www.hindawi.com/ journals/jdr/2017/1478294/.

Olokoba, A.B., Obateru, O.A.,Olokoba, L.B. (2012). Type 2 diabetes mellitus: review of current trends. Oman Med J, 27 (4), 269-273. doi: 10.5001/omj.2012.68.

Paul, G., Harch, M.D., \& Virginia, M.C., (2016). Hyperbaric Oxygen Therapy: Tird Edition.

Peleg, Ronit. K., Fishlev, G., Bechor, Y., Bergan,J., Friedman, M., Koren, S., Tirosh, A, \& Efrati, S. (2013). Effects of hyperbaric oxygen on blood glucose levels in patients with diabetes mellitus, stroke or traumatic brain injury and healthy volunteers: a prospective, crossover, controlled trial. Diving and Hyperbaric Medicine , 4(43), 2018-221.

PERKENI. (2015). Konsensus pengelolaan dan pencegahan diabetes melitus tipe 2 di Indonesia.. file://C:/Users/User/Downloads/
Documents/konsensus.pdf.

Polit, D.F., \& Beck, C.T. (2010). Essensial of nursing. Wolters Kluwer Health: Lippincott Company.

Poretsky, Leonit. (2010). Principles of diabetes mellitus. London: Spriner. Retrieved from https://books.google.co.id/.

Sugiyono. (2010). Metode penelitian kuantitatif, kualitatif dan R \& D. Bandung: Penerbit Alfabeta.

Sudoyo A,W., Setiyohadi, B., Alwi, I., Simadibrata, M., \& Setiati S. (2009). Buku Ajar Ilmu Penyakit Dalam.Edisi 5. Jakarta: Interna.

Tjokroprawiro, A. (2007). Buku ajar ilmu penyakit dalam. Surabaya: Airlangga University Press.

Wilkinson, D., Chapman,I.M., \& Heilbronn, L.K. (2012) Hyperbaric oxygen therapy improves peripheral insulin sensitivity in humans. Diabet Med, 29 (8), 986-9.doi: 10.111/j.1464-5491.2012.03587.x.. 